ALDO TAGLIABUE

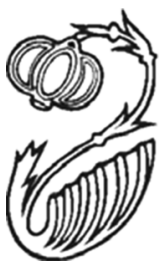

\title{
Aelius Aristides' Sacred Tales: A Study of the Creation of the "Narrative about Asclepius”
}

\begin{abstract}
Aelius Aristides' Sacred Tales is a complex literary text, and its first book - the diary — puzzles scholars, as it has no parallel in the entire work. This paper offers a justification for this section by arguing for a deliberate contrast between the diary and Books 2-6 of the Sacred Tales, as a result of which the latter section is crafted as a narrative about Asclepius. I will first identify a large series of shifts in the ST: starting with Book 2, change concerns the protagonist, which from Aristides' abdomen turns to Asclepius, the narrator, dream interpretation, genre, and arrangement of the events. Secondly, I discuss the impact of these shifts upon the readers' response: while the diary invites the readers to relive the everyday tension between known past and unknown future, the spatial form of Books 2-6 creates the opposite effect, turning the readers' attention away from the human flow of time towards Asclepius, and leading them to perceive features of his divine time.
\end{abstract}

The Sacred Tales (from now onwards ST), Aelius Aristides' first-person account of his healing brought about by Asclepius, is a very complex literary work $^{1}$ which presents a highly controversial feature: the $S T$ starts with a long diary about Aristides' diseases and then, after a second prologue, Books 2 to 6 continue

I would like to thank the anonymous referees at Classical Antiquity for their helpful criticism. I owe special gratitude to the editor, Mark Griffith, for his numerous and valuable suggestions. I am also grateful to Jonas Grethlein, Athanassios Vergados, Nikoletta Kanavou, Luuk Huitink, Jakob Lenz, David Warrington, Emmanuela Schoinoplokaki, and Benjamin Allgaier for commenting on earlier drafts of this article. The research for this article was made possible by the European Research Council under the European Union's Seventh Framework Programme (FP/2007-2013) / ERC Grant Agreement n. 312321 (AncNar).

1. For recent surveys of the rich bibliography on the ST, see Petsalis-Diomidis 2010: 122-25 and Korenjak 2005: 215-17. Scholars of this text can be divided into two groups: some emphasize the rhetorical mark of this text and take it as an autobiography that "uses the god as an excuse to trumpet the author's own talents and successes" (Petsalis-Diomidis 2006: 194). Other scholars offer a religious reading of the text as an aretalogy, arguing that it is "a praise of the god through the personal

Classical Antiquity, Vol. 35, Issue 1, pp. 126-146. ISSN: 0278-6656(p); 1067-8344(e)

Copyright (C) 2016 by The Regents of the University of California. All rights reserved. Please direct all requests for permission to photocopy or reproduce article content through the University of California Press's Rights and Permissions website at http://www.ucpressjournals.com/reprintinfo.asp. DOI: $10.1525 /$ ca.2016.35.1.126 
as an account of his life characterized by loose time markers. Scholars have often been puzzled by this twofold structure and have either interpreted the diary as the work of a different author or taken this shift between Book 1 and the following ones as an inconsistency in Aristides' literary agenda. ${ }^{2}$

This paper sheds new light on this issue, as it takes the twofold composition of the $S T$ as a deliberate strategy for crafting, in Books 2-6, a narrative focused on Asclepius.

In the first section of the paper, I will identify a large list of differences between Book 1 and Books 2-6: from the second book onwards Asclepius replaces Aristides' abdomen as the protagonist of the $S T$, and this shift is reinforced by other textual features, namely, a change in narrator, dream description, genre, and arrangement of the events. As a result, the differences between Book 1 , the diary, and Books 2-6, the "narrative about Asclepius," point out the intrusion of the god in the second part of the ST. More precisely, since narrative is a temporal medium, ${ }^{3}$ the difference in the arrangement of the events deserves special attention: using narratological categories, the two sections of the ST produce an opposition between a marked sequential narrative and one in which sequentiality is underplayed. For this second type of narrative I draw on the metaphorical notion of "spatial form," which Frank, Smitten, and Daghistany identify in novels and Grethlein extends to every narrative: "spatial form in its simplest sense designates the techniques by which novelists subvert the chronological sequence inherent in narrative." Elimination of time is the most significant among these: as argued by Smitten, "time can be eliminated from narrative (or at least severely attenuated) by ... the removal of temporal indicators, and the scrambling of the time scheme." ${ }^{\prime 6}$ Other spatial devices are juxtaposition and repetition of events, ${ }^{7}$ as well as the retrospective stance of the narrator, which by granting readers control over the past offers them a non-sequential perception of the plot. ${ }^{8}$

In the second section of the paper, I will discuss the implication of this analysis of the $S T$ for the readers' response, ${ }^{9}$ with the help of a heuristic take on structuralist

testimony of the author" (2006: 195). The two recent monographs written on the ST confirm this trend, as Downie 2013 belongs to the former group, Petsalis-Diomidis 2010 to the latter.

2. See section 1 of this paper for bibliographical references.

3. See, e.g., Ryan 2007: 24: "narrative is about the temporality of existence."

4. See Frank 1991, Smitten and Daghistany 1981, Grethlein 2013: 340-48 and Grethlein forthcoming.

5. Smitten and Daghistany 1981a: 13.

6. Smitten 1981: 25 .

7. See again Smitten and Daghistany 1981a: 13.

8. For the interpretation of retrospective narratives as spatial ones, see Grethlein forthcoming.

9. Whenever in my discussion I refer to readers, I generally denote the readership of the Imperial era contemporary to Aelius Aristides (second century CE). Petsalis-Diomidis' reconstruction appears to be plausible: "The $S T$ is addressed to a social elite and celebrates the religious dimensions of that social identity, but is not addressed to an exclusive audience of initiates. . . . Aristides certainly assumes his reader's familiarity with the basic Asklepian rituals of incubation, and with the occurrence of divine manifestations and interventions, but these were widely known, whatever people's attitudes 
narratology. ${ }^{10}$ In Grethlein's view, by reconfiguring time, narrative leads readers to relive the human tension between the well-known past and the open future within the safe frame of the text, usually through the mediation of characters. ${ }^{11}$ In the light of this framework, I will argue that the diary of the $S T$, with its marked sequentiality, invites the readers to relive this tension and experience suspense about the development of the plot. Conversely, in Books 2-6 the narrator's adoption of a spatial form creates the opposite effect-distancing or even exempting readers from this same tension and suspense. Although every narrative oscillates between capitalizing upon or underplaying sequentiality, I would argue that the $S T$, because of its focus on the divine, makes this tension specifically fruitful, as it uses spatial form to divert the readers away from sequential form (a reconfiguration of human time) and lead them to perceive features of Asclepius' divine time. ${ }^{12}$

This hypothesis is supported by the fact that in the ancient world Asclepius, unlike traditional Greek gods, ${ }^{13}$ was traditionally considered to be a transcendent deity - one whose nature is beyond the human grasp and whose time differs from the human one,${ }^{14}$ and this view is also held by Aristides, as he repeatedly mentions Asclepius' providence and frequent interventions into human life. To conclude, the "narrative about Asclepius" induces readers to perceive features of the god's transcendent time. Within this framework epiphanic moments stand out as partial exceptions, since in a more traditional way - through sequential form and suspense - they draw the readers' attention to two further qualities of Asclepius, the unpredictability and intensity of his action.

to these claims" (2010: 129-30). Within this framework familiar to Asclepius' cult, ancient readers (or at least most of them) were likely to accept the content of the $S T$-with regard to both Aristides' life and Asclepius' interventions - as plausible. In this respect, I agree with Israelowich 2012: 29 that "it appears that the ancient readers of the Sacred Tales all believed they contained credible biographical information regarding Aristides." I do not exclude the possibility that specific readers could take a different attitude — such as an ironical one towards the divine (see Whitmarsh 2004: 446) - but in this paper I am interested in discussing what appears to be the most likely and common response to the $S T$.

10. I follow Grethlein and Rengakos 2009: 3, who argue that "technical analysis of narrative ought not however to be an end in itself, but needs to be made fruitful for interpretation." For a more general definition of heuristic narratology in the context of actual narratologies, see Kindt and Müller 2003: 212-15.

11. See Grethlein 2010, who uses structuralist narratology in dialogue with phenomenology.

12. In relating the spatial form of narrative to divine time I follow Grethlein's study of Augustine's Confessions (2013: 340-48).

13. On the lack of transcendence in traditional Greek gods, see Bremmer 1994: 5: "Whereas the Christian world-view increasingly separates God from this world, the gods of the Greek were not transcendent but directly involved in natural and social processes." See also Bremmer 1994: 30: "Subject to reproduction and birth but exempt from death, the gods worshipped by the Greeks are imperishable but not eternal."

14. On the inclusion in Greek religion of a minority of transcendent gods, see Mitchell and Van Nuffelen 2010a: 9, paraphrasing Frede's argument (2010): "some ancient thinkers-Antisthenes, Chrysippus, and Galen - developed a conception of a single transcendent god, which at least approximates to the criteria for the belief in one god that was established by later doctrinal monotheisms." On the inclusion of Asclepius in this group, see Versnel 2011: 418 who defines Asclepius as an "omnipotent and omniscient deity." 
Finally, in the conclusion of the paper I will attempt to relate the ST's approach to Asclepius to the widespread interest in ancient literature in reconfiguring the divine, with a special relevance to the Imperial world. Since Homer, ancient Greek writers have introduced gods in narrative texts without any significant formal change, as shown by the fortune of the epiphanic motif. Within this tradition Aristides stands out for his extensive transformation of narrative to speak about Asclepius - a literary choice reflecting Aristides' attempt to convey the transcendent nature of Asclepius through the sequential medium of narrative. This choice is possibly comparable to Apuleius' approach to Isis - another transcendent goddess - in the last book of his Metamorphoses, and by pointing out this similarity I hope to invite scholars to undertake systematic research on the way in which narrative form changes when a text speaks about the divine - in the literature of the Imperial period and in ancient literature as a whole.

\section{PART ONE: THE INTRUSION OF ASCLEPIUS IN THE SECOND PART OF THE SACRED TALES}

As was recently pointed out by Janet Downie, Book 1 of the $S T$ "stands apart from the others because it is organized as a diary of dreams and symptoms." "Scholars"-Downie continues_- "have generally assumed that after making a beginning with the first Logos, Aristides took stock and decided to expand the scope of his commemorative project." ${ }^{\prime 15}$ Only Dorandi has recently argued that Book 1 was not written by Aristides himself but by one of his students, but his arguments are not fully convincing: Dorandi focuses on loose narrative connections in $S T 1^{16}$ and on the close similarities between the two prologues at the beginning of Book 1 and $2,{ }^{17}$ but I agree with Downie that "since the ST consistently flout normal patterns of rhetorical organization, it seems problematic to judge the text by ordinary standards of literary unity and coherence, however basic." 18 What, then, can we make of this apparent puzzle within Aristides' work?

A comparative analysis between Book 1 and Books 2-6 points to areat number of differences between them that require further interpretation: the change in protagonist, narrator, dream description, genre affiliation, and arrangement of the events.

\section{A. THE DIARY VS. THE NARRATIVE ABOUT ASCLEPIUS: A SHIFT IN THE PROTAGONIST}

The $S T$ as a whole concern Aristides' healing from his disease through Asclepius' help. However, while Book 1 narrates this process with an emphasis on the former's

15. Downie 2013: 44-45, with further bibliographical references.

16. See Dorandi 2005: 54.

17. See Dorandi 2005: 62. Dorandi fails to note important differences between prologue 1 and 2 , such as the appearance of memory in the latter.

18. Downie 2013: 45. 
body, the rest of the work focuses on the latter's intervention, generating a shift in the protagonist of the narration.

In Book 1, at the very end of the prologue, we read:

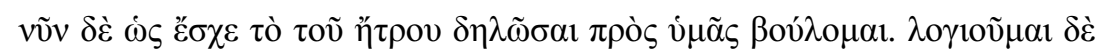

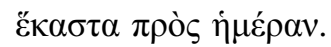

ST 1.4

But now I wish to indicate to you the condition of my abdomen. I shall reckon each matter day by day. ${ }^{19}$

This sentence introduces the protagonist of the diary, Aristides' abdomen, and the narration of its diseases runs until chapter 59, when a new account focused on Aristides' tumor begins.

In Book 2, after the second prologue, Aristides relates his journey back from Italy and the doctors' inability to cure him. When the situation seems hopeless, Asclepius comes to heal Aristides, and from this point onwards, the text focuses on $\tau \tilde{\omega} v \gamma \varepsilon \gamma \varepsilon v \eta \mu \varepsilon$ -

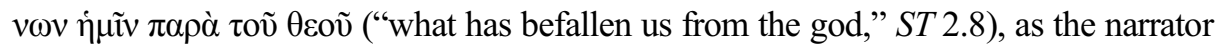
himself declares in one of his recusationes. As a result, in Books 2-6 the god becomes the protagonist of the narration, making this section the "narrative about Asclepius."

This shift is confirmed and reinforced by the way in which the god is portrayed in each section. Although the god intervenes throughout the diary, ${ }^{20}$ the narration places his focus on Aristides: nothing is said about the god's nature and physical appearance and Asclepius' name is hardly ever mentioned - only twice (cf. 1.23 and 1.38). Conversely, the "narrative about Asclepius" contains multiple mentions of the god's name - four of them appear in the first forty chapters of Book 2 alone. The first mention is particularly emphatic, since the god is addressed by Aristides with the ritual acclamation $\mu \varepsilon ́ \gamma \alpha \varsigma$ ó A $\sigma \kappa \lambda \eta \pi$ เó ("Great is Asclepius," ST 2.7), ${ }^{21}$ and a few words ear-

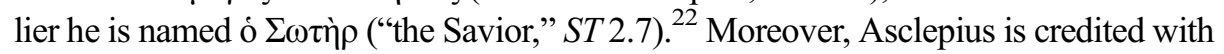
specific features such as providence, which I will comment on in section $2 \mathrm{~A}$ of the paper. Finally, in three dreams — which I will shortly classify as epiphanic - the god assumes a physical body to interact with Aristides. ${ }^{23}$ Overall, this framework confirms that from Book 2 onwards Asclepius becomes the new protagonist of the narrative.

\section{B. THE DIARY VS. THE “NARRATIVE ABOUT ASCLEPIUS": A LARGE SERIES OF DIFFERENCES}

This shift is accompanied by a larger series of formal differences between the two sections of the $S T$.

19. For the text of Aelius' Sacred Tales, see Dindorf 1964. For the translations, I used Behr 1981.

20. See $S T 1.23,1.45$ bis, 1.52 bis, 1.58 .

21. On the traditional use of this formula in Asclepius' cult, see Macalister 1996: 111.

22. For the other occurrences of Asclepius' name, see 2.18, 2.21 and 2.40.

23. In 2.18 Asclepius moves and uses the fingers to count the years, in 2.40 he turns Aristides aside, and in 4.50 the god nods, moves his hand, and speaks. 


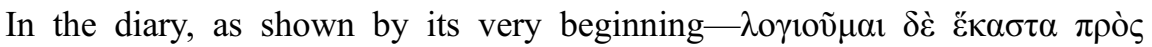
$\dot{\eta} \mu \varepsilon \varepsilon_{\rho} \alpha \nu$ ("I shall reckon each matter day by day," ST 1.4) - the narrator is Aristides and can be classified as an "experiencing I," as he "narrates the events exactly as he experienced and understood them at the time they took place." ${ }^{24}$ Conversely, in the "narrative about Asclepius" Aristides is still the narrator, but he has changed in some way. Firstly, he is guided by Asclepius:

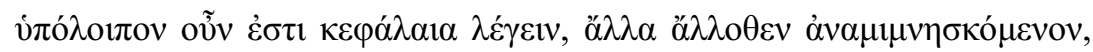

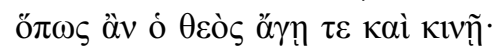

ST 2.4

The only thing left is to speak in summary fashion, as I remember different things from different sources, in whatever way the god will lead and stimulate me.

Moreover, in Books 2-6 the narrator's persona becomes more visible than in the diary, in two respects. Firstly, in the passage above - as in some others ${ }^{25}$ —Aristides indulges in comments about his narratorial activity (thus becoming a "narrating I," one who narrates "making use of his ex eventu knowledge"). ${ }^{26}$ Secondly, in a few exceptional cases he maintains his status as "experiencing I" by describing his own reaction to Asclepius in the form of a bodily and multisensorial response. ${ }^{27}$ The implication of both attitudes for the reader's response will be commented in section $2 \mathrm{~B}$ of this paper.

A second difference between Book 1 and the following ones concerns dream description. In the diary, dreams are characterized by openness to interpretations. Let us analyze a test case:

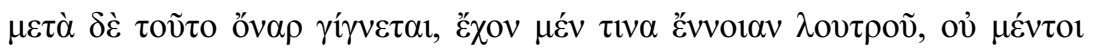

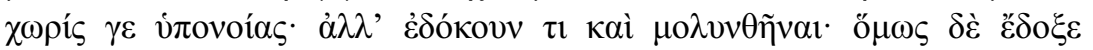
$\lambda$ ov́ $\sigma \alpha \sigma \theta \alpha \mathrm{l} . .$.

ST 1.7

After this, there was a dream which contained a notion of bathing, not, however, without a second-order meaning. I dreamed that I had been in some way befouled. Nevertheless I decided that I would bathe. ...

Here Aristides faces a hermeneutic challenge and his decision to bathe will turn out to be wrong. The same pattern occurs in 1.26, when Aristides risks his own interpretation of the dreams and then his friend Zosimus even makes him recognize that he has given a false interpretation (1.27). ${ }^{28}$ Conversely, in the

24. de Jong 1991: 1. This distinction between narrators originally comes from Spitzer 1928: 447-49.

25. See $S T$ 2.24, 37, 45, 60, 71, 73; 4.63, 68, 70, and Castelli 1999: 206-207.

26. de Jong 1991: 1 .

27. See esp. ST 2.32-33 and 2.21-23. For a detailed embodied analysis of some passages of the ST, see Tagliabue forthcoming.

28. For other occurrences of the same pattern, cf. 1.52 and 1.55. 
"narrative about Asclepius" the god confirms his new key role as he leaves no room for interpretation by giving Aristides clear orders: ${ }^{29}$ in one of the first narrated dreams in Book 2, Asclepius invites Aristides to perform his purgation

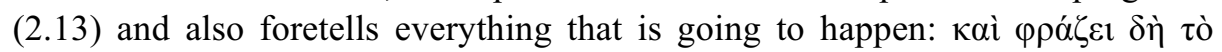
$\pi \tilde{\alpha} \nu$ ("and he made everything clear," 2.13). At 2.34 Aristides is uncertain about what to do with the dream he has received and Asclepius sends another character an identical and reassuring dream (2.35). Divine interventions result in that the opening of dreams of Book 1 is abandoned. Moreover, in Books 2-6 only Aristides' companions - not the narrator himself - try to offer a wrong interpretation of a dream (2.72).

A third variation between the diary and the "narrative about Asclepius" concerns genre affiliation. Scholars have suggested two plausible generic affiliations for the first section: the Epidemics account in the Hippocratic corpus and the aretalogical texts dedicated to Asclepius. ${ }^{30}$ The link with the former is closer, as it is from that corpus that Aristides borrows the form of the diary and some medical language. ${ }^{31}$ Moreover, scholars have clearly pointed out the ST's intertextual debt to the Odyssey, ${ }^{32}$ which generates a precise "association between Aristides and Odysseus." 33 It is striking, however, that no mention of the Odyssey is made in the diary, as a result of which this section and the "narrative about Asclepius" also diverge in genre affiliation. This variation further highlights the text's shift from Aristides' abdomen to Asclepius: the Odyssey offers in fact an ideal model for a narrative focused on a god, because of its epic status and Athena's key role within it. ${ }^{34}$ Moreover, Downie has recently pointed out close similarities between the $S T$ and the prose hymns written by Aristides. ${ }^{35}$ The hymnic genre can thus be considered as another generic model of the $S T$, and, also in this case, references to it exclusively concern Aristides' "narrative about Asclepius." It is only from Book 2 onwards that hymnic features appear, such as an invocation to the god (2.4) and three elements which I will discuss later in the paper, namely narratorial queries about where to start, the account of the god's epiphanies, and the rhetoric of gratitude to Asclepius for his interventions. ${ }^{36}$

29. Downie 2013: 80 identifies, in the form of the "double dream" in Book 1, another way through which Aristides establishes "interpretive control by virtue of divine endorsement." I agree with her that the "double dream" eliminates the openness of interpretation, but I do not see how this stratagem is necessarily caused by divine intervention.

30. For the suggestion of the former generic association, see Pearcy 1992 and Downie 2013: 93-96. For the suggestion of the latter generic model, see Boulanger 1923: 171 and Petsalis-Diomidis 2008: 378.

31. See Pearcy 1992.

32. See Kindstrand 1973, Schröder 1987, and Whitmarsh 2004.

33. Whitmarsh 2004: 446.

34. Cf. Bierl 2004: 47: "From her traditional Olympian level Athena functions as the mastermind of the narrative."

35. Downie 2013: 127-53.

36. For the relevance of these features to the hymnic tradition, cf. Bremer and Furley 2001. 
Finally, the last difference between Book 1 and Books 2-6 concerns the arrangement of the events: since narrative is by definition a temporal medium, this is arguably the most important shift. In a simplified but effective formula, the $S T$ are constructed as the opposition of a marked sequential narrative and one in which sequentiality is deemphasized, namely a spatial narrative.

The diary, almost by definition, is characterized by a sequentiality described with day-by-day markers. ${ }^{37}$ This is clear from the very beginning of this section:

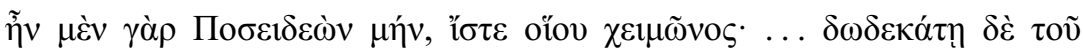

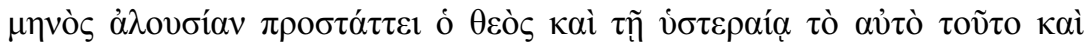

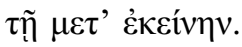

$$
\text { ST } 1.5-6
$$

It was the month of Poseidon, and what a winter it was! ... On the twelfth of the month, the god instructed me not to bathe, and the same on the next day, and on the day after that.

Conversely, at the beginning of Book 2, after a few lines a different arrangement of the events emerges - a complex and even chaotic one. ${ }^{38}$ After a brief description of his sickness and a narratorial pause, Aristides says:

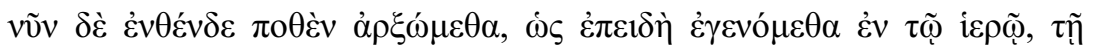

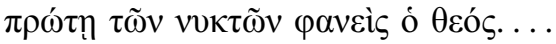

Now let us begin at about this point, since when we entered the Temple on the first night, the god appeared....

"On the first night" is one of the very few precise chronological markers in this section: after it day-by-day sequentiality is both deemphasized and alternated with a different arrangement of the events.

To begin with, the account of the god's beneficial actions towards Aristides has a strongly retrospective quality: the "narrative about Asclepius" often anticipates the positive outcome of his interventions before telling them, as we see here:

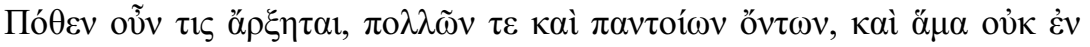

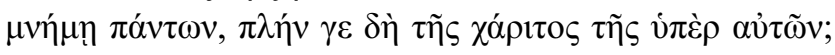

37. See Castelli 1999: 202.

38. Scholars have often commented upon the chaotic chronology of Aristides' text. For a recent assessment, see e.g. Schmitz 2013: 99: "genau der Faktor Zeit aber ist in den Heiligen Berichten problematisch." For older contributions along similar lines, see Pearcy 1988, Castelli 1999 (with detailed and good narratological analysis), and Korenjak 2005: 217-18. Downie 2013: 45 identifies the existence of an "associative rather than a temporal logic" in the ordering of Books 3 and 5. In my view, this issue can be better addressed if the narrative about Asclepius is compared with both the god's portrait in Books 2-6 and the diary. Finally, Bittrich 2009: 119 argues that Aristides' narration in Books 2-6 is "dreamlike." This definition, however, is based on the controversial assumption that any account of dreams implies a lack of sequentiality. 
Where should one begin, when there are so many different things and at the same time when all are not remembered, if not for the gratitude generated by them?

By mentioning this gratitude, Aristides implies that the god has already taken care of him, and the events subsequently narrated can have but a positive outcome.

Moreover, within this retrospective account single episodes are juxtaposed with different criteria. To begin with, sequentiality links some of Asclepius' interventions, but, unlike the diary, temporal markers are often quite general: $\mu \varepsilon \tau \hat{\alpha} \delta \dot{\varepsilon} \tau \alpha \tilde{v} \tau \alpha$,

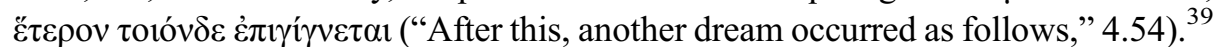

Secondly, temporality is sometimes overtly underplayed or almost suspended: in some passages Aristides expresses his uncertainty about the arrangement of the events, as we see here:

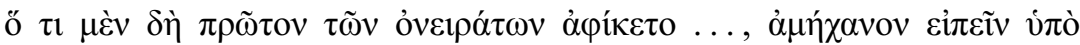

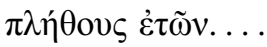

ST 4.15

It is impossible to say through the length of time whatever dream came first. ... 40

In other passages Aristides even omits chronological markers. ${ }^{41}$ The same effect of suspension is produced by the use of repetition and thematic juxtaposition ${ }^{42}$ as devices to link the narrated events.

Thirdly, a frequent use of analepses creates disorder in the arrangement of the events, an effect once highlighted by Aristides with the metaphor of the ladder:

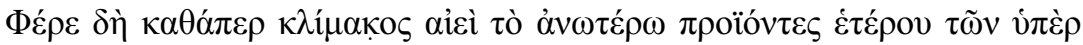
$\tau \alpha \tilde{\tau} \tau \mu \nu \eta \mu о v \varepsilon v ́ \sigma \omega \mu \varepsilon v$.

ST 4.100

Come now, as if we were ever ascending a ladder, let us recall another of the things before this. ${ }^{43}$

To sum up, unlike the day-by-day sequentiality, Books 2-6 combine retrospection with a tendency to deemphasize sequentiality, suspension, and disordering of chronology. ${ }^{44}$ As anticipated in the introduction, each of these elements, because

39. See also $S T 3.34,4.58,5.19$ bis, 5.29 .

40. See also 2.9, 3.24, 4.40, and Castelli 1999: 199.

41. See $S T 5.38$ and 5.49 .

42. The catalogue of baths is a case in point, which I will discuss below.

43. See also $S T 2.37,2.60,4.2,4.13,4.58$, and 4.105 .

44. Castelli 2009: 407 argues that in Book 5, unlike in the previous ones, "il turbine temporale ... si placa," as analepses no longer occur. As a result, she concludes that here another narratological category becomes dominant, namely the spatial circularity of the described journeys. Although I agree with Castelli's point about analepses, I maintain that Book 5 constitutes a unity with Books 2-4 with respect to the take on time: general sequentiality and suspension of temporality do in fact occur in the last extant book of the $S T$, as well as in Books 2-4. 
of their underplaying of the sequential form of narrative, can be metaphorically defined as spatial. In Books 2-6 Aristides introduces not only a new protagonistAsclepius - but also other new formal features that emphasize the intrusion of the god in this section and construct it as a narrative focused on him.

Moreover, as already noticed, the "narrative about Asclepius" includes four apparitions of the god to Aristides, one in the company of Athena and another in the company of Serapis (3.46). Scholars have already commented upon the epiphanic nature ${ }^{45}$ and the "highly developed sense of location" 46 of these passages. Platt has defined them as "agalmatophanies," as they describe statues that appear "as animated forms of the deities they represent." 47 My interest lies in how narrative reconfigures time in these passages. As epiphanies and by describing a "sudden appearance and equally rapid disappearance of a deity in human perception,"48 these sections stand out as exceptions in the "narrative about Asclepius," as they capitalize on sequentiality. It is still significant, however, that, unlike that of the diary, the sequential form of the epiphanies focuses not on a human protagonist (Aristides' abdomen) but on Asclepius, and points out two further features of the god, the unpredictability and intensity of his actions. This shift further confirms the creation of the "narrative about Asclepius" from Book 2 onwards.

In section two of the paper, I will discuss the implication of this interpretation for the readers' response to the text. Before doing so, I will offer a final confirmation that the twofold structure of the $S T$ is the result of a deliberate strategy.

\section{THE END OF BOOK 1: A TRANSITION FROM THE DIARY TO THE "NARRATIVE ABOUT ASCLEPIUS"}

In Book 1 the diary section terminates in chapter 58, and the last chapters are dedicated to the account of Aristides' tumor (1.61-68), the story of Zosimus, Aristides' foster-father (1.69-77), and, very briefly, to that of his nurse Philumene (1.78). Choosing two exemplary points, I will argue that this section, which differs in form from Aristides' diary (as it lacks the day-by-day sequentiality), introduces features of Books 2-6 that relate to Asclepius: the god's achievement of a hermeneutic control over dreams and the attribution to the narrative of a retrospective quality. In other words, this section works as a transition between the diary and the "narrative about Asclepius."

In 1992 Pearcy pointed out "the contrast within the tumor story between the medicine of the god and that of his mortal rivals": Asclepius' prescriptions are very different from those of the doctors, but by following the former (1.63) Aristides achieves

45. See e.g. Downie 2013: 108. At 2.18 the term "epiphany" is explicitly mentioned, while at 2.41 the protagonist of the scene is Athena, the "epiphanic" goddess par excellence in the Odyssey (see Bierl 2004: 47).

46. Platt 2011: 261.

47. Platt 2011: 261.

48. Pax 1955: 20. For scholarship on epiphany in ancient literature, see Platt's survey (2011: 9) and Petridou 2016. 
healing (1.64). ${ }^{49}$ Interestingly, Asclepius' clear orders interrupt the opening of dream interpretation which was typical of the diary section; the same change - as we knowis going to take place in the "narrative about Asclepius."

Moreover, during the account of the healing Aristides makes a narratorial

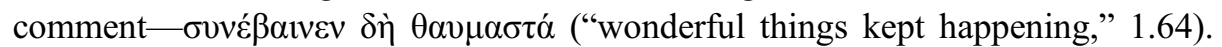
This anticipation of the positive outcome of Asclepius' interventions becomes even clearer in the following account of Zosimus' death (69-77), which is introduced thus:

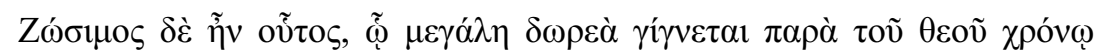
vँ $\tau \varepsilon \rho \circ v^{*}$

ST 1.69

Zosimus was the man to whom a great gift was given by the god later on.

This early focus on the positive outcome of the god's actions introduces into the text the same retrospective quality that we have identified in the "narrative about Asclepius."

As a result, with their transitional role the last chapters of Book 1 confirm the existence of a deliberate division in the $S T$ meant to construct a narrative of the divine in Books 2-6.

\section{PART TWO: THE READERS' PERCEPTION OF ASCLEPIUS' TRANSCENDENT TIME}

In the second part of this paper, I shall discuss the impact of the twofold structure of the $S T$ upon the readers.

In the last decades both philosophical and literary critical approaches have drawn our attention to the structural similarities between human experience and narrative. ${ }^{50}$ More precisely, human life is characterized by the tension between a well-known past and an open future, and, in Grethlein's view, by reconfiguring time, narrative can allow readers to relive this tension in a safe space. At the core of this reconfiguration lies the distinction, coined by Russian formalists, between "fabula," the story in simple chronological and causal sequence, and "sjuzet," its artistic presentation in narrative. If the "sjuzet" (or a specific section of it) maintains the chronological sequence of the "fabula," readers are led to relive through the text the tension between past experiences and future expectations. Conversely, narratives (or sections of it) filled with anticipations or spatial features exempt readers from reliving that tension. Moreover, if the narrative's interplay with

49. Pearcy 1992: 606.

50. Ricoeur's critique of Husserl's and Heidegger's concept of a pure phenomenology of time is the most influential study of this kind (1984-1988). Ricoeur identifies in narrative the means to reconcile "objective time" and time as actually experienced by human beings. 
human expectations is mostly related to the arrangement of the events in the plot, this process can be reinforced by the readers' identification with characters, a process which plays an important role in an "autobiographical" and "intensely personal narrative" ${ }^{51}$ like the $S T:{ }^{52}$ for this reason, I will now assess how both the arrangement of the events and Aristides' persona affect the readers' response to the $S T$.

\section{A. READERS' RESPONSE TO DIFFERENT ARRANGEMENTS OF EVENTS}

Relying upon Grethlein's view of narrative, I would argue that the diary of the $S T$, with its day-by-day sequentiality and the narrator's silence about the positive outcome of the healing, lets readers relive the tension proper to human life between past experiences and future expectations. Suspense about the development of the plot is often aroused in the readers with the mediation of the narrative's focalization on Aristides, who is the "experiencing I," as we see in the following passage:

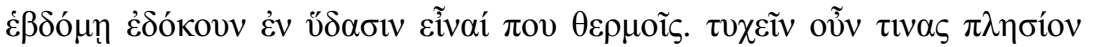

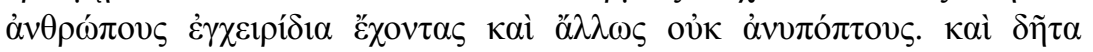

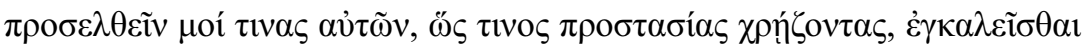

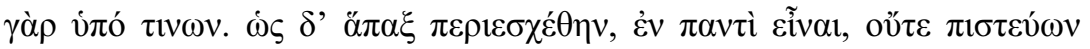

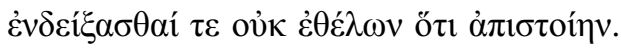

ST 1.22

On the twenty-fourth, I dreamed that I was at the warm springs. Some men with daggers and otherwise behaving suspiciously happened to be nearby. Finally some of them approached me, as if desiring some defense, for they said that they were accused by certain men. When I had been surrounded, I was greatly disturbed, neither trusting them nor wishing to show that I was distrustful.

Aristides' disturbance here triggers a similar feeling in the readers and generates in them suspense about the development of this narrated dream.

Conversely, in Books 2-6 the retrospective quality of the narrative along with the other spatial devices listed in section 1B of the paper stops the readers' suspense regarding the future, distancing or even exempting them from reliving the human tension between past experiences and future expectations. Although a devaluation of this tension can be produced in any kind of narrative, ${ }^{53}$ in Books $2-6$ of the $S T$ it assumes a special twist because of its focus on the divine: as I anticipate in the

51. Whitmarsh 2004: 441. On the $S T$ as an autobiography, see also Israelowich 2012: 24-26 and Israelowich 2015: 67, defining this text as "the sole first-person prose narrative of a sick person to survive from classical antiquity."

52. Cf. Grethlein 2010: 318, who mentions how "a consistent focalization of a plot through a character" can "align the experience of a reader with that of the character."

53. As shown by Frank's study of modern novels (1991) "spatial form" normally occurs in texts which do not focus on the divine. 
introduction, here spatial form diverts the readers' attention away from a marked sequential form (a reconfiguration of human time) and leads them to perceive features of Asclepius' transcendent time.

This hypothesis is plausible since, as argued in the introduction, Asclepius was traditionally considered to be a transcendent god. Moreover in Books 2-6 Aristides qua "narrating I" overtly reflects upon Asclepius' divine time, and such a reflection matches the spatial features proper to this section of the narrative. To begin with,

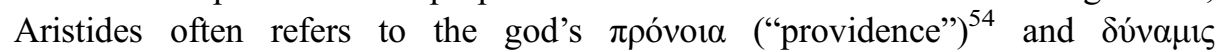
("power") ${ }^{55}$ and to the remarkable frequency and variety of his interventions, ${ }^{56}$ as shown by the following emblematic passage:

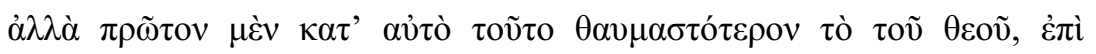

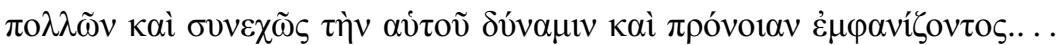

ST. 2.55

But first of all, in itself, this activity of the god is rather wonderful, since he often and frequently revealed his power and providence....

With statements like this, Aristides seems to perceive Asclepius as an entity having both a nature and a time different from those of humans. That Aristides has exactly this perception of the god is confirmed by the following passage from another speech delivered by the same author, An Address Regarding Asclepius:

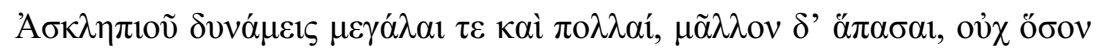

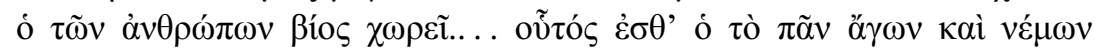

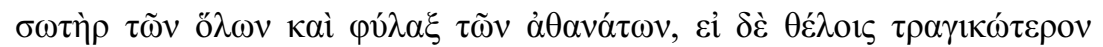

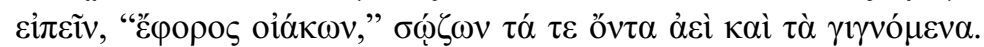

Or. 42.4

Great and many are the powers of Asclepius, or rather he possesses all powers, beyond the scope of human life.... It is he who guides and directs the Universe, savior of the Whole and Guardian of what is immortal, or if you should prefer an expression of tragedy, "the overseer of the helm," who preserves both eternal being and that which comes into being. 57

Additionally, in the $S T$ the god's providence aligns well with the text's strong retrospective quality, which gives readers foreknowledge about the outcome of narrated

54. See $S T 1.3,1.67,1.74,2.2,2.55,2.59,3.40$ and 4.36. At 1.49 and 3.37 the same term $\pi \rho o ́ v o t \alpha$ lacks a divine context and means "human care."

55. See $S T 2.30,2.55,2.73$.

56. See $S T 1.3,2.11,2.15,5.38$.

57. Strikingly, within this passage Aristides references the $S T$ as a text in which the same ideas were already told. Although the passage Aristides is recalling likely belongs to the lost part of Book 6 (see Behr 1981: 416n.7), this reference reinforces the likeliness of the ST's transcendent reading of Asclepius. 
events. Through the retrospective form of narrative, then, the readers of the $S T$ are invited to perceive a feature of Asclepius' transcendent time.

A similar consideration applies to the frequency and variety of the god's interventions, as these two features match the special arrangement of the events proper to the "narrative about Asclepius," especially its disordered chronology, juxtapositions, and repetitions. This interpretation is reinforced by the long narratorial comment at 2.24-25. In its first part, Aristides overtly refers to spatial devices of his narrative, namely thematic juxtaposition, chronology of a general kind ( $\tau 1 v \alpha \tau \tilde{\omega} v$ $\dot{\varepsilon} v \mu \varepsilon \dot{\varepsilon} \sigma \omega$, , "some intermediate events," 2.24), and analepsis. Immediately after, this narratorial strategy is related to the remarkable frequency and variety of Asclepius' interventions:

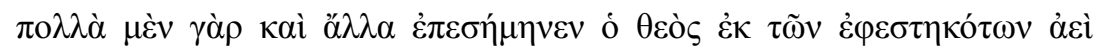

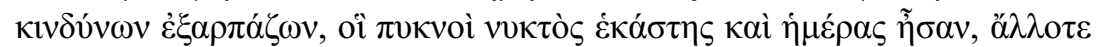

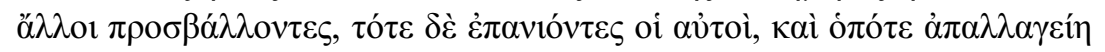

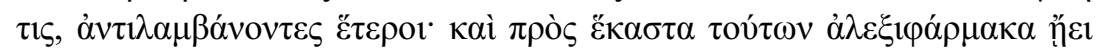

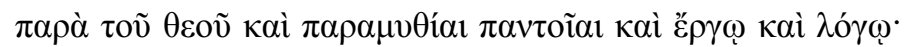

For the god also gave me many other signs when he snatched me from the dangers which ever beset me and which were frequent every night and day, different ones confronting me at different times, sometimes the same ones recurring, and whenever one was quit of them, others taking their place. And antidotes for each of these things came from the god, and he consoled me in various ways by word and deed.

Here Aristides' association between the spatial features of his narration and Asclepius' divine nature is made through the mediation of the diseases: their frequency and variety which are expressed in the first phrase extend to the god's healing action in the following sentence, as Asclepius finds antidotes for each of Aristides' sicknesses.

In conclusion, by responding to the change in narrative form which underlies the $S T$ - and especially to the opposition between a marked sequential and a spatial narrative - readers are asked first to relive the human tension between past expectations and future experiences, and then to turn their attention to some qualities of Asclepius' transcendent time.

\section{B. THE READERS' SPECIAL RESPONSE TO EPIPHANIC MOMENTS}

In this analysis of the readers' response to the $S T$, the frequent epiphanic moments also deserve attention, as through the mediation of Aristides' persona they too induce readers to perceive qualities of Asclepius, namely the unpredictability and intensity of his action, two features which, unlike the ones listed above, have a more general kind of connection with time. Moreover, in two specific 
passages, the communication of these divine qualities to the readers is reinforced by Aristides' role as an "experiencing" rather than a "narrating" I.

In the first passage Aristides describes the multiple epiphanies of Asclepius in his life:

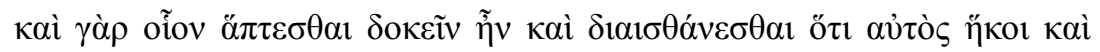

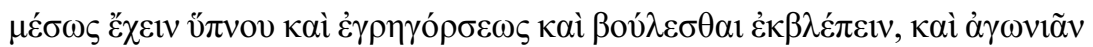

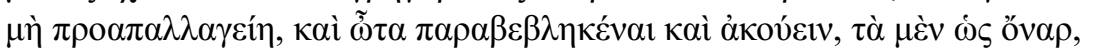

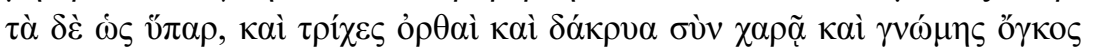

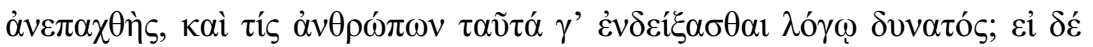

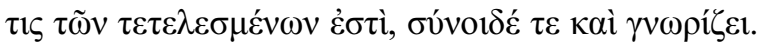

ST 2.32-33

For there was a seeming, as it were, to touch him and to perceive that he himself had come, and to be between sleep and waking, and to wish to look up, and to be in anguish that he might depart too soon, and to strain the ears and to hear some things as in a dream, some as in a waking state. Hair stood straight, and there were tears with joy, and the pride of one's heart was inoffensive. And what man could describe these things in words? If any man has been initiated, he knows and understands.

Here Aristides presents a human response to divine action that is multisensorial, as it involves the whole of his body - its perception, seeing, touching, and hearing. Moreover, one feature is especially relevant to the narrative reconfiguration of time, namely Aristides' perception that the god has arrived and his anguish that the god might depart. This epiphanic moment generates suspense in Aristides, but one of a different quality from that of the diary, as it draws his attention not to the general development of the plot but to the elusivity and unpredictability of Asclepius.

Moreover, the "narrative about Asclepius" includes a specific kind of epiphany, Aristides' healing baths, in which, as recently shown by Downie, ${ }^{58}$ the narrator "appropriates the epiphanic function for himself, by making his own body a vehicle of divine presence." 59 The first of these passages stresses the intensity of the moment in which Asclepius transforms and heals Aristides' body:

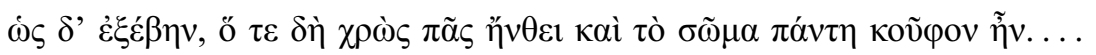

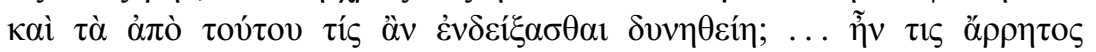

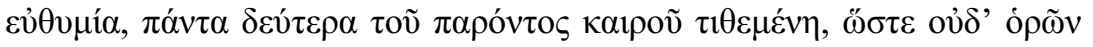

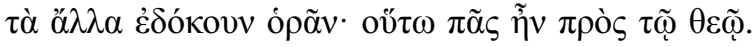

ST 2.21-23

When I came out, all my skin had a rosy hue and there was a lightness throughout my body.... Who could tell what came next? ... There was a certain inexplicable contentment, which regarded everything as less than

58. See Downie's detailed analysis of these passages at 2013: 102-13.

59. Downie 2013: 107-108. 
the present moment, so that even when I saw other things, I seemed not to see them. Thus I was wholly with the god.

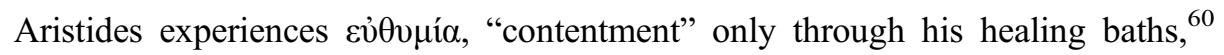
and in this passage this feeling is said to regard "everything as less than the present moment": these words suggest that Aristides' attention is fully captured by the

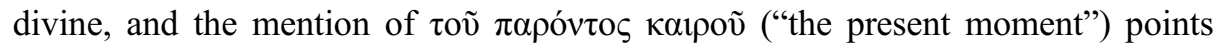
out that Aristides conceives of Asclepius as a presence giving an extraordinary intensity to the instant of his intervention.

Overall, by describing his own bodily experiences of the god Aristides enriches the number of the qualities of Asclepius he wants to recall.

To what extent, however, are readers meant to participate in this bodily experience of the narrator? On the basis of a close analysis of these two passages, I would argue that the text might invite readers to imitate Aristides - but does not oblige them to do so.

At the conclusion of the first passage above we have just read:

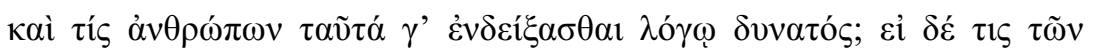

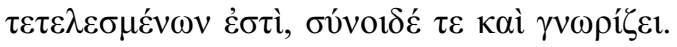

And what man could describe these things in words? If any man has been initiated, he knows and understands.

These words present Aristides' perception of the divine as accessible only to a group of initiates. Aristides likely considers himself a member, since he often portrays himself in the $S T$ as a special devotee of Asclepius. The position of the readers is more difficult to establish, but because of the conditional clause some of them might feel invited to become initiated too and imitate Aristides' experience. ${ }^{61}$

The same invitation is offered by Aristides' first epiphanic bath, this time through the mediation of the spectators assisting to the immersion:

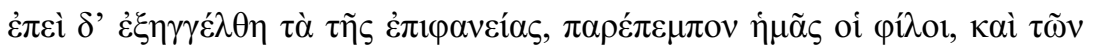

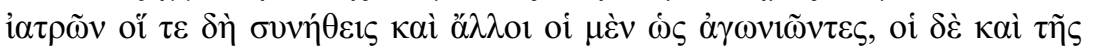

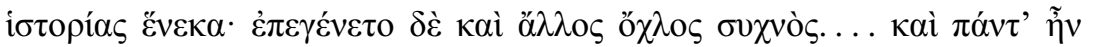

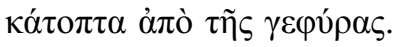

ST 2.20

When the divine manifestation was announced, friends escorted us and various doctors, some of them acquaintances, and others who came either out of concern or even for the purposes of investigation. There was also another great crowd.... And everything was visible from the bridge.

60. See 2.23, 2.49, 2.73, and 5.3.

61. Here I am very close to Petsalis-Diomidis' interpretation of this passage, for which see 2006: 200: "the conclusion of the passage clearly aims to elicit a personal response or memory in the reader." 
The suspense and visual curiosity that this mixed audience provides for the narrator's immersion are noticeable, and possibly function as trigger for the external readers of the $S T$, making their identification with Aristides and their reenactment of his perception of Asclepius through the body more likely.

As a result, epiphanic moments in the $S T$-with the help of Aristides' bodypoint out the unpredictability and intensity of the god's action and support the way in which the "narrative about Asclepius" induces readers to perceive features of this god.

\section{CONCLUSION}

I began this paper by saying that Aristides' $S T$ is a very complex literary work, which still presents its readers with some unresolved puzzles. By undertaking a narratological analysis of this text, I hope to have offered a new interpretation of its twofold structure focused on the shift in protagonist from Aristides' abdomen to Asclepius. Flagrant formal differences between Book 1 and the following books - culminating in the opposition between a marked sequential and a spatial narrative - have been explained as part of a deliberate strategy aimed at giving room to the god in the text. Moreover, the construction in Books 2-6 of a divine narrative affects the readers' response to the text, leading them to perceive some of the qualities of this god and of his transcendent time through the shape of the narrative.

In conclusion to this paper, a final question needs to be addressed: how does Aristides' creation of the "narrative about Asclepius" relate to the ancient literature's widespread interest in narrating about the divine?

At a first glance, Aristides' focus on Asclepius matches the interest in the gods typical of the literature contemporary to him and also, possibly, the emergence in the Imperial period of a more personal approach to the divine. ${ }^{62}$ The Imperial era produced many narratives focused on gods, and, as shown by both Platt's and Kindt's research, a great number of these texts describe epiphanic encounters between individual people and gods or semidivine characters, as we see in Dio's Discourse 12, Pausanias' Description of Greece, Philostratus' Heroicus, and Pseudo-Lucian's Amores. ${ }^{63}$

Upon closer examination, however, Aristides' divine narrative also distinguishes itself from the existing literature on the divine. Since Homer, anthropomorphic gods appear to intrude into ancient texts without any significant change in narrative form,

62. See Julia Kindt's programmatic words: the Graeco-Roman world "witnesses an increase in Greek personal religion and a turn towards a more spiritual experience of the divine" (2012: 30).

63. See Platt 2011: 215-52 and Kindt 2012: 155-89 for references. Divine epiphany also occurs in the extant ancient Greek novels, where, however, as recently shown by Cioffi, this motif is often used as a metaphor "when an internal audience reacts to the hero or, most often, the heroine of the novel as if he or she were a god or goddess" (Cioffi 2014: 1). 
and the popularity of epiphany throughout ancient literature confirms that ancient narrators were at ease in introducing the divine in their sequential stories. ${ }^{64}$ Another sign of this ease is the way in which Greek myth, as attested in different texts, often describes the gods' life from their birth to their old age, assigning to them a human kind of temporality. ${ }^{65}$ Against this framework, the extensive transformation of narrative form proper to the $S T$ claims some originality, for two different reasons. Firstly, Aristides has decided to focus his narrative on a god-Asclepius - whose nature and time differs from those of humans: the $S T$ give further evidence of the emergence of transcendent gods in ancient religion and especially in the Imperial era. ${ }^{66}$ Secondly, the creation of the ST's divine narrative through the contrast between sequential and spatial form within the same text reflects Aristides' profound awareness of the relationship between time and narrative. In the Genettian basic definition, "one would define narrative without difficulty as the representation of ... a sequence of events." Since transcendent gods are not subject to this sequence, whoever narrates their actions needs to compromise between the sequential structure of his own language and the freedom of the divine from such constraint. With his extensive exploitation of spatial form, Aristides appears to find his own way to make this compromise, one that leads readers to perceive qualities of Asclepius' divine time.

With this choice Aristides is possibly comparable to Apuleius in his take on Isis - another transcendent goddess - in the last book of his Metamorphoses. In this text, the appearance of Isis in Book 11-a goddess who is overtly defined as transcending time (11.7.3: "parens temporum")-is accompanied with a slowing down of the narration, an effect that is reinforced by the many ekphraseis of this book. ${ }^{68}$ This retardation-which can be defined as a spatial feature of the narrative - has been taken by scholars as a device enabling readers "to enhance their impression of a real divine epiphany" and "to experience various sensory impressions of religious practice", 69 in other words, the spatial narrative of Book 11 induces readers to perceive features of Isis' transcendence.

In the light of this analogy, the $S T$ 's approach to the divine turns out to be original but not exclusive. I therefore hope that this paper will stimulate further research on this matter, so that we might get a clearer idea of the extent to which

64. See Petridou 2016.

65. A case in point is Callimachus' Hymn 1 focused on the birth of Zeus.

66. On the emergence of Pagan transcendent gods as a peculiar trait of the Imperial era-a phenomenon called "Pagan monotheism," see e.g. Athanassiadi and Frede 1999 and Mitchell and Van Nuffelen 2010b.

67. Genette 1982: 127.

68. A comprehensive analysis of the scholarship on Book 11 of the Metamorphoses as well as of the treatment of Isis is well beyond the scope of this paper. For this narratological analysis, I refer to Keulen et al. 2015: 21-24.

69. Keulen et al. 2015: 23. 
in the Imperial era-and possibly within ancient literature as a whole-narrators transformed the shape of the narrative when they decided to speak about the divine. $^{70}$

Universität Heidelberg

aldo.tagliabue@skph.uni-heidelberg.de

\section{BIBLIOGRAPHY}

Athanassiadi, P., and M. Frede, eds. 1999. Pagan Monotheism in Late Antiquity. Oxford.

Behr, C. A. P. 1981. Aelius Aristides, The Complete Works. Vol. II: Orations XVII-LIII. Leiden.

Bierl, A. 2004. "Turn on the Light! Epiphany, the God-like Hero Odysseus, and the Golden Lamp of Athena in Homer's Odyssey." ICS 29: 43-61.

Bittrich, U. 2009. "Geträumte Dichtung und gedichtete Träume." In S. Heiser and C. Hom, eds., Gedächtnisparagone, Intermediale Konstellationen, 113-30. Göttingen.

Boulanger, A. 1923. Aelius Aristide et la sophistique dans la province d'Asie au IIe siècle de notre ère. Paris.

Bremer, J. M., and W. D. Furley, eds. 2001. Greek Hymns: Selected Cult Songs from the Archaic to the Hellenistic Period. Vol. 1. Tübingen.

Bremmer, J. 1994. Greek Religion. Oxford.

Castelli, C. 1999. "Intenzionalità espressiva e ordine della narrazione nei Discorsi sacri di Elio Aristide." Acme 52.1: 197-212.

- 2009. "Dominante spaziale e struttura argomentativa nel $V$ Discorso Sacro di Elio Aristide." Rhetorica 27.4: 404-19.

Cioffi, R. L. 2014. "Seeing Gods: Epiphany and Narrative in the Greek Novels." AN 11: 1-42.

Clay, J. S. 1989. The Politics of Olympus: Form and Meaning in the Major Homeric Hymns. Princeton.

Daghistany, A. and J. R. Smitten. 1981. Spatial Form in Narrative. Ithaca and London.

de Jong, I. J. F. 1991. Narrative in Drama: The Art of the Euripidean Messenger-Speech. Leiden.

- 2007. "Homer." In I. J. F. de Jong and R. Nünlist, eds., Time in Ancient Greek Literature, 17-37. Leiden.

Dindorf, W. 1964. Aristides. Vol. 1. Hildesheim.

Dorandi, T. 2005. "Il 'Diario' dei sogni di Elio Aristide: Per una interpretazione del primo discorso sacro." Segno e Testo 3: 51-59.

Downie, J. 2013. At the Limits of Art. A Literary Study of Aelius Aristides' Hieroi Logoi. Oxford.

70. Studies on ancient Greek literature have already identified a few more formal features peculiar to the divine, namely the anomalous use of past tenses (e.g., the apparent confusion of tenses in the descriptions of gods, evident in Hesiod's Theogony 1-115: see Clay 1989: 27-29; see also the existence of timeless aorists in the Homeric Hymns, for which see again Clay 1989: 23-29 and Bakker 2002, who interprets them rather as "perceptual aorists"), the frequency of simultaneous narrations (see de Jong 2007: 34), and the introduction of "eternal prolepses" (see Nünlist 2007: 61) in describing the gods' acquisition of privileges. None of these features, however, has been used so far to problematize the role of the divine in narratives on a larger perspective. 
Flannery, F. 2008. Inquiry into Religious Experience in Early Judaism and Christianity. Atlanta.

Frank, J. 1991. The Idea of Spatial Form. New Brunswick.

Frede, M. 2010. "The Case for Pagan Monotheism in Greek and Graeco-Roman Antiquity." In Mitchell and Van Nuffelen 2010a, 53-81.

Genette, G. 1982. Figures of Literary Discourse. Trans. A. Sheridan. New York.

Grethlein, J. 2010. "The Narrative Reconfiguration of Time beyond Ricœur." Poetics Today 31: 313-29.

- 2013. Experience and Teleology in Ancient Historiography: Futures Past from Herodotus to Augustine. Cambridge.

- Forthcoming. Aesthetic Experiences, Ancient and Modern: The Significance of Form in Narratives and Pictures.

Grethlein, J., and A. Rengakos, eds. 2009. “Introduction.” In Narratology and Interpretation: The Content of Narrative Form in Ancient Literature, 1-11. Berlin and New York.

Harris, W. V., and B. Holmes, eds. 2008. Aelius Aristides between Greece, Rome, and the Gods. Leiden and Boston.

Holmes, B. 2008. “Aelius Aristides’ Illegible Body.” In Harris and Holmes, 81-114.

Israelowich, I. 2012. Society, Medicine and Religion in the Sacred Tales of Aelius Aristides. Leiden and Boston.

. 2015. Patients and Healers in the High Roman Empire. Baltimore.

Keulen, W., et al. 2015. Apuleius Madaurensis Metamorphoses, Book XI, Text, Introduction and Commentary. Leiden.

Kindstrand, J. F. 1973. Homer in der Zweiten Sophistik. Studien zur Homerlektüre und dem Homerbild bei Dion von Prusa, Maximos von Tyros und Ailios Aristeides. Uppsala.

Kindt, J. 2012. Rethinking Greek Religion. Cambridge.

Kindt, T., and M. M. Müller. 2003. "Narrative Theory and/or/as Theory of Interpretation.” In T. Kindt and M. M. Müller, eds., What is Narratology? Questions and Answers Regarding the Status of a Theory, 205-19. Berlin and New York.

Korenjak, M. 2005. “'Unbelievable Confusion': Weshalb sind die 'Hieroi Logoi' des Aelius Aristides so wirr?" Hermes 133: 215-34.

Macalister, S. 1996. Dreams and Suicides: The Greek Novel from Antiquity to the Byzantine Empire. London.

Mitchell, S., and P. Van Nuffelen, eds. 2010a. One God: Pagan Monotheism in the Roman Empire. Cambridge.

- 2010a. "Introduction." In Mitchell and Van Nuffelen 2010a, 1-15.

, eds. 2010b. Monotheism between Pagans and Christians in Late Antiquity. Leuven.

Pax, E. 1955. Epiphaneia. Ein religionsgeschichtlicher Beitrag zur biblischen Theologie. Munich.

Pearcy, L. T. 1988. "Theme, Dream and Narrative. Reading the Sacred Tales of Aelius Aristides." TAPA 118: 377-91.

- 1992. "Diagnosis as Narrative in Ancient Literature." AJPh 113.4: 595-616.

Petridou, G. 2016. Divine Epiphany in Ancient Greek Literature and Culture. Oxford.

Petsalis-Diomidis, A. 2006. "Sacred Writing, Sacred Reading: The Function of Aelius Aristides' Self-Presentation as Author in the Sacred Tales." In J. Mossman and B. McGing, eds., The Limits of Ancient Biography, 193-211. Swansea.

- 2008. "The Body in the Landscape: Aristides' Corpus in the Light of the Sacred Tales.” In Harris and Holmes, 131-50. 
2010. Truly Beyond Wonders: Aelius Aristides and the Cult of Asklepios. Oxford. Platt, V. J. 2011. Facing the Gods: Epiphany and Representation in Graeco-Roman Art, Literature and Religion. Cambridge and New York.

Ricoeur, P. 1984-1988. Time and Narrative. Trans. K. McLaughlin and D. Pellauer. 3 vols. Chicago.

Ryan, M. L. 2007. “Toward a Definition of Narrative.” In D. Herman, ed., The Cambridge Companion to Narrative, 22-35. Cambridge.

Schmitz, T. A. 2013. "Aelius Aristides: Der Sophist und sein Gott.” In U. Baumann and K. A. Neuhausen, eds., Autobiographie: Eine interdisziplinäre Gattung zwischen klassischer Tradition und (post-) moderner Variation, 95-106. Göttingen.

Schröder, H. O. 1987. "Das Odysseusbild des Ailios Aristides." RhM 130: 350-56.

Smitten, J. R. 1981. "Introduction: Spatial Form and Narrative Theory." In Daghistany and Smitten, 15-34.

- 1981a. "Editor's Preface.” In Daghistany and Smitten, 13-15.

Spitzer, L. 1928. Stilstudien II. Munich.

Tagliabue, A. 2016. “An Embodied Reading of Epiphanies in Aelius Aristides' Sacred Tales." In Ramus forthcoming.

Versnel, H. S. 2011. Coping with the Gods: Wayward Readings in Greek Theology. Leiden and Boston.

Whitmarsh, T. 2004. “Aelius Aristides.” In I. J. F. de Jong, R. Nünlist, and A. Bowie, eds., Narrators, Narratees, and Narratives in Ancient Greek Literature, 441-47. Leiden. 2007. "Philostratus." In de Jong and Nünlist, 413-30. 